\title{
Chemical Resistance and Catalytic Activity of Copper in the Process of Electrooxidation of Ethanol in Strong Alkaline Media
}

\author{
Klara Tarantseva ${ }^{1 *}$, Natalia Politaeva ${ }^{2}$, Konstantin Tarantsev ${ }^{3}$, Mikhail Yakhkind ${ }^{1}$, \\ Ajay Kumar Mishra ${ }^{4}$ \\ ${ }^{1}$ Department of Biotechnology and Environmental Protection, Penza State Technological University, 1a/11, \\ Baidukova Prospect/Gagarina Street, Penza 440039, Russian Federation \\ ${ }^{2}$ Graduate School of Hydraulic and Power Engineering Construction, Peter the Great St. Petersburg \\ Polytechnic University, 29 Polytechnicheskaya str., St. Petersburg 195251 Russian Federation \\ ${ }^{3}$ Department of Machinery Production, Penza State University, 40 Krasnaya str., Penza 440026 Russian \\ Federation \\ ${ }^{4}$ Academy of Nanotechnology and Waste Water Innovations, University of South Africa, $5^{\text {th }}$ floor Phapha \\ building Florida, Johannesburg 1709, South Africa
}

\begin{abstract}
The possibility of using copper $(\mathrm{Cu})$ as a catalyst in nonflowing membraneless alkaline fuel cells was investigated. In the present study, the interface between two immiscible liquids served as a virtual membrane. We studied two immiscible liquid systems: Ethanol $+\mathrm{K}_{3} \mathrm{PO}_{4}+\mathrm{H}_{2} \mathrm{O}$ (No. 1 electrolyte) and Ethanol $+\mathrm{KOH}+\mathrm{H}_{2} \mathrm{O}$ (No. 2 electrolyte). Cyclic voltammetry, pulse chronoamperometry, and gas-liquid chromatography were used to study the corrosion resistance and catalytic activity of ethanol oxidation on Cu. Analyses of chromatograms obtained after charging and discharging the fuel cells revealed the presence of ethanol oxidation products, mainly in the form of acetaldehyde, which indicates the predominant mechanism of $\mathrm{C}_{2}$ oxidation of ethanol in the studied system. That is, with the release of two and four electrons during the oxidation of alcohol and the formation of acetaldehyde and acetic acid. Anodic currents of $\mathrm{Cu}$ dissolution in No. 1 electrolyte were an order of magnitude lower than in the No. 2 electrolyte. The catalytic activity of $\mathrm{Cu}$ during the oxidation of ethyl alcohol EtOH in the electrolyte with potassium hydroxide was at least five times higher than in the electrolyte with potassium phosphates, at almost the same $\mathrm{pH}$ values. The surface compounds on the $\mathrm{Cu}$ electrode in the first electrolyte were composed mainly of monovalent and bivalent $\mathrm{Cu}$ compounds, whereas they were composed of trivalent $\mathrm{Cu}$ compounds in the second electrolyte. Thus, the possibility of using $\mathrm{Cu}$ as a catalyst for the oxidation of EtOH in alkaline nonflowing membraneless fuel cells has been established. To further increase the catalytic activity of $\mathrm{Cu}$ and expand its commercial attractiveness as a catalyst, further research is needed to optimize its composition and structure and create bimetallic and multimetallic $\mathrm{Cu}$-based electrodes, including nanostructured ones.
\end{abstract}

Keywords: $\quad$ Copper; Ethanol fuel cells; Membraneless

\section{Introduction}

Alternative energy sources, such as fuel cells, have become more attractive in recent years due to their potential in preserving natural fossil fuels and in decentralized energy

*Corresponding author's email: krtar2018@bk.ru, Tel.: +7412- 577726 doi: 10.14716/ijtech.v12i4.4851 
systems in Industry 4.0 (Berawi et al., 2019; 2020). Due to the growing demand for such energy sources, attention has focused on improving the safety and extending the service life of fuel cells and minimizing pollution from used batteries (Masudin et al., 2019; Kusrini et al., 2020). Ethanol is a safe source of energy in fuel cells that meets all these requirements. However, the ethanol oxidation process is hampered by the need for expensive catalysts based on platinum and palladium, which significantly increases the cost of ethanol fuel cells (Kusrini et al., 2018). Therefore, scientists worldwide continue to search for inexpensive and effective catalysts based on non-noble metals.

The use of copper $(\mathrm{Cu})$ as a catalyst for the electrochemical oxidation of alcohols in alkaline media has attracted considerable attention in recent years due to the development of alcohol fuel cells (Giri and Sarkar, 2016). Copper oxides have attracted particular attention, with a number of studies showing that they can improve catalytic activity and adsorption properties (Giziński et al., 2020; El Attar et al., 2021). Previous studies investigated the catalytic activities of $\mathrm{Cu}$ as a base (Wu et al., 2017; Fahim et al., 2018) and as a component in multicomponent catalysts (Freitasa et al., 2014; Almukhlifia and Burns, 2015; Oznuluer et al., 2018). A number of studies showed that metal oxides copper (I) oxide - an inorganic compound $\left(\mathrm{Cu}_{2} \mathrm{O}\right)$ and copper (II) oxide - an inorganic compound $(\mathrm{CuO})$ fixed on the surface of a copper $(0)(\mathrm{Cu})$ electrode (CE) exhibited excellent electrocatalytic activity and stability (Sato et al., 2012; Wan, 2013; Gao et al., 2018; Scherzer, 2019). Li et al. (2014) used CEs with a $\mathrm{Cu} / \mathrm{Cu}_{2} \mathrm{O} / \mathrm{CuO}$ layer deposited on the electrode as a sensor for glucose determination. They showed that these CEs had high sensitivity due to a electrocatalytic reaction on the porous surface of crystalline $\mathrm{CuO}$ and an improved ability to transfer electrons, which was facilitated by the Schottky transition between $\mathrm{Cu}$ and $\mathrm{Cu}_{2} \mathrm{O}$. Electrons generated by an electrochemical process can be more efficiently transferred from the oxide to the CE due to the large driving force created by the Schottky barrier at the $\mathrm{Cu} / \mathrm{Cu}_{2} \mathrm{O}$ interface. Thus, $\mathrm{Cu}_{2} \mathrm{O}$ can serve as a suitable intermediate in a $\mathrm{CuO}$ reaction layer.

Prior to cyclic voltammetry, the dependence of the formation of various compounds on the applied potential remained unclear. Cyclic voltammetry gives reproducible results when studying the selectivity of catalysts (Mundinamani and Rabinal, 2014; Aristov and Habekost, 2015; Khalil et al., 2018; Hardi and Rahman, 2020), as the shape and atomic composition of the final films of compounds on metal can be controlled by ramping the potential, reaction duration, and the charge.

Several mechanisms for the oxidation of $\mathrm{Cu}$ in alkalis and alcohols have been described (Wan et al., 2013; Liu et al., 2020; Giziński et al., 2020). Paixao et al. (2002) and Bueno and Paixao (2011) studied the oxidation of $\mathrm{Cu}$ in $0.1 \mathrm{M} \mathrm{KOH}$. They revealed four peaks in the anodic region associated with the oxidation of $\mathrm{Cu}$. These peaks were due to the formation of $\mathrm{Cu}_{2} \mathrm{O}, \mathrm{CuO}$, and copper (II) hydroxide is an inorganic crystalline or amorphous substance $\left(\mathrm{Cu}(\mathrm{OH})_{2}\right.$ ) layers on the electrode surface. In addition to these, other particles can be deposited on the electrode surface, depending on the potential, $\mathrm{pH}$ of the solution, conditions of mass transfer, aging processes, and surface restructuring. Xray diffraction, together with other methods, revealed three layers on the surface of the electrode after electrolysis: a green layer $\left(\mathrm{Cu}_{2} \mathrm{O}\right)$, a blue layer $(\mathrm{CuO})$, and a black layer $\left(\mathrm{Cu}(\mathrm{OH})_{2}\right.$ and copper (III) as an intermediate product in the reaction of ethanol electrooxidation $\left(\mathrm{CuOOH}^{-}\right)$(Paixao and Beriotti, 2004; Giri and Sarkar, 2016). After electrolysis in $0.1 \mathrm{M} \mathrm{KOH}, \mathrm{Cu}(\mathrm{OH})_{2}$ was the dominant component on the electrode surface. Panah et al. (2019) analyzed the formation of various particles of copper oxides and hydroxides in an alkaline medium according to the potential (low or high). They confirmed the formation of $\mathrm{Cu}_{2} \mathrm{O}$ and $\mathrm{CuO}$ at low potential and $\mathrm{Cu}(\mathrm{OH})_{2}$ at high potential. 
Giziński et al. (2020) showed that nanostructured copper oxides formed via anodizing had a highly-developed surface area and that they exhibited unique adsorption properties to crucial reaction intermediates. Therefore, electrodes with nanostructured copper oxides can be considered as platinum group metals electrodes substituents in fuel cells. El Attar et al. (2021) demonstrated that ethanol molecules are totally oxidized on $\mathrm{Cu}_{2} \mathrm{O}$ nanodendrites, with the formation of $\mathrm{CO}_{2}$ molecules as a final product (El Attar et al., 2021). Thus, $\mathrm{Cu}$ is a very promising catalyst for the oxidation of alcohols. However, there are no reports on the possibility of using $\mathrm{Cu}$ as a catalyst in nonflowing membraneless fuel cells. In these fuel cells, the phase boundary between two immiscible liquids serves as the membrane. The main advantage of these fuel cells is the absence of a membrane (as in membrane fuel cells) and laminar fluid flow (as in microfluidic fuel cells), which greatly reduces the cost of the design and simplifies their operation. The absence of a membrane, which cost is up to $30 \%$, reduce the cost of a fuel cell. The absence of pumps to circulate the fuel an oxidants simplifies the operation and maintenance the fuel cells.

Previously, we proposed a type of membraneless alcohol fuel cell (Tarantseva et al., 2020a; 2020b; 2020c). Our investigation revealed the possibility of separating phases only in a few highly alkaline two-phase ethanol-electrolyte-water systems. The choice of immiscible fluid systems for fuel cells were conducted on the basis of the following requirements: the two phases should not be mixed; both phases shall have electrical conductivity; one phase (anolyte) should contain the maximum amount of alcohol, the other phase (catholyte) should contain the minimum amount of alcohol. In our previous research, we proposed three strongly alkaline two-phase "ethanol-electrolyte-water" systems: based on potassium carbonate (Ethanol $\left.+\mathrm{K}_{2} \mathrm{CO}_{3}+\mathrm{H}_{2} \mathrm{O}\right)$, potassium phosphate (Ethanol $\left.+\mathrm{K}_{3} \mathrm{PO}_{4}+\mathrm{H}_{2} \mathrm{O}\right)$ and potassium hydroxide (Ethanol $\left.+\mathrm{KOH}+\mathrm{H}_{2} \mathrm{O}\right)$. For these systems, binodal curves were constructed, and the conditions for the existence of a two-phase system were determined. In the first system, during oxidation of ethanol the deposition of potassium carbonate on the surface of the anode led to blocking of pores and impairment of its operation. Therefore, further studies the process of oxidation of ethanol on copper electrodes were carried out using the other two systems based on potassium phosphate and potassium hydroxide.

There appears to be no published data on the chemical resistance and catalytic activity of $\mathrm{Cu}$ in the Ethanol $+\mathrm{K}_{3} \mathrm{PO}_{4}+\mathrm{H}_{2} \mathrm{O}$ (No. 1 electrolyte) and Ethanol $+\mathrm{KOH}+\mathrm{H}_{2} \mathrm{O}$ (No. 2 electrolyte) during ethanol oxidation. Some studies have characterized the behavior of $\mathrm{Cu}$ during the oxidation of alcohols in buffer solutions of potassium hydroxide ( $\mathrm{KOH})$ and sodium hydroxide $(\mathrm{NaOH})$ in membrane fuel cells and microfluidic membraneless fuel cells (Paixao et al., 2002; Abd El Haleem and Abd El Aal, 2006; Wan, 2013; Giri and Sarkar, 2016). To study the possible use of copper in the oxidation of ethyl alcohol in nonflowing membraneless fuel cells, information on the catalytic activity and corrosion resistance of $\mathrm{Cu}$ in two proposed systems based on potassium phosphate and potassium hydroxide is required.

In this work, we describe for the first time the chemical resistance and catalytic activity of $\mathrm{Cu}$ in ethanol electrooxidation in a new type of nonflowing membraneless fuel

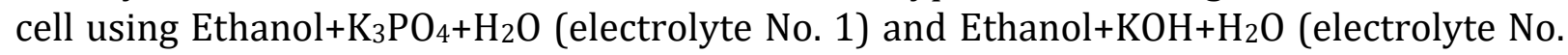
2) systems.

\section{Methods}

Redox processes occurring on a $\mathrm{Cu}$ electrode used as a catalyst for ethanol oxidation in No. 1 and No. 2 electrolytes were studied by cyclic voltammetry, which was used to obtain information about the limiting stages of process of oxidation and it mechanism. By 
examining cyclic voltammograms (CVs) as a function of the scan rate, it was determined whether the electron transfer was reversible, quasi-reversible, or irreversible (Mundinamani and Rabinal, 2014; Aristov and Habekost, 2015). A potential scan rate of 1 $\mathrm{mV} / \mathrm{s}$ was chosen as the lower limit of scanning, and the upper limit was $100 \mathrm{mV} / \mathrm{s}$. The electrode used in this study was made of M0 $\mathrm{Cu}$ (Russia), with a $\mathrm{Cu}$ content of at least $99.9 \%$. The dimensions of the electrodes were $150 \times 100 \mathrm{~mm}$.

To compare the catalytic activity of $\mathrm{Cu}$ in the oxidation of ethanol, its pulsed polarization was carried out in both electrolytes. Polarization was carried out by pulsed switching of the potential of the $\mathrm{Cu}$ electrode from $-600 \mathrm{mV}$ (holding time of $1 \mathrm{~s}$ to +400 $\mathrm{mV}$ (holding time of $10 \mathrm{~s}$ ). The pulse cycle consisted of 10 steps of 30 pulses, repeated 9 times.

Catalytic activity and corrosion resistance of copper were studied in two different immiscible fluid systems. The first system was obtained based on Ethanol and aqueous solutions of potassium phosphate salts, $\mathrm{pH}=11.8$ (electrolyte No.1). The second system was obtained based on Ethanol and an aqueous solution of potassium hydroxide, $\mathrm{pH}=$ 13.1 (electrolyte No.2). Earlier, binodal curves were experimentally constructed for these ethanol-electrolyte-water systems, and the conditions for their separation were determined (Tarantseva et al., 2020c). In the studied systems, stable phase separation was maintained throughout the entire research period (1 year), with the formation of a virtual membrane by the phase interface. The main components of the lower phase were water and phosphates or potassium hydroxide (hereafter referred to as the "salt layer"), depending on the type of electrolyte. The main component of the upper phase was ethanol and water (hereafter referred to as the "alcohol layer").

Cyclic voltammograms and pulsed polarization were performed using a P-45X potentiostat-galvanostat and ES-8 software (Electrochemical Instruments, Russia). A twoor three-electrode system for connecting an electrochemical cell was used, depending on the type of experiment. A saturated silver chloride electrode was used as a reference electrode, and a platinum electrode was used as an auxiliary electrode.

The efficiency of the oxidation process of $\mathrm{EtOH}$ on $\mathrm{Cu}$ was assessed in both liquid systems using chromatograms. A Kristall 2000M gas chromatograph with Chromatek Analytic 2.5 software (ZAO SKB Chromatek, Russia) and ZB-FFAP capillary column (Phenomenex, USA). To analyze the surface of the working electrodes, an METAM-P1 (LOMO, Russia) metallographic microscope was used.

\section{Results and Discussion}

Figure 1 shows the CVs of $\mathrm{Cu}$ in the salt and alcohol layers of electrolyte No. 1 at different scan rates.

According to a Pourbaix diagram (Takeno, 2005) for $\mathrm{Cu}$ in the aqueous phase in the considered range of potentials and $\mathrm{pH}, \mathrm{Cu}_{2} \mathrm{O}$, which is insoluble in water and alcohol, formed first (Equation 1):

$$
\mathrm{Cu}_{2} \mathrm{O}+\mathrm{H}_{2} \mathrm{O}+2 \mathrm{e}^{-} \rightarrow 2 \mathrm{Cu}+2 \mathrm{OH}^{-}
$$

Under further anodic polarization, the following reaction took place, depending on the solution $\mathrm{pH}$ (Equation 2):

$$
\mathrm{Cu}(\mathrm{OH})_{2}+2 \mathrm{e}^{-} \rightarrow \mathrm{Cu}+2 \mathrm{OH}^{-}
$$

with the formation of poorly soluble copper (II) hydroxide $\left(\mathrm{Cu}(\mathrm{OH})_{2}\right)$, which is a very weak base and can dissolve in concentrated alkali solutions with the formation of complexes with a bright blue color. 


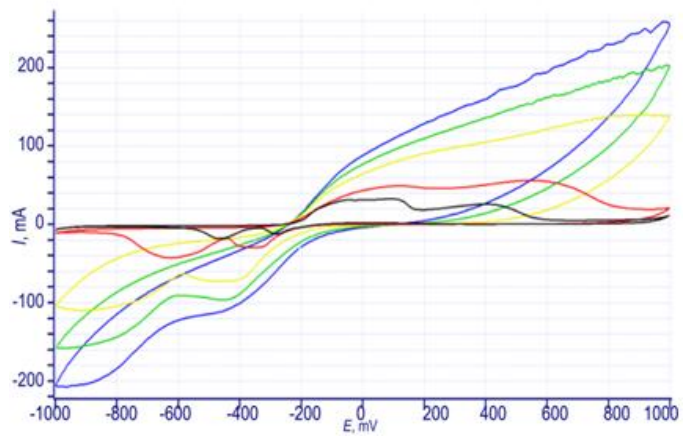

(a)

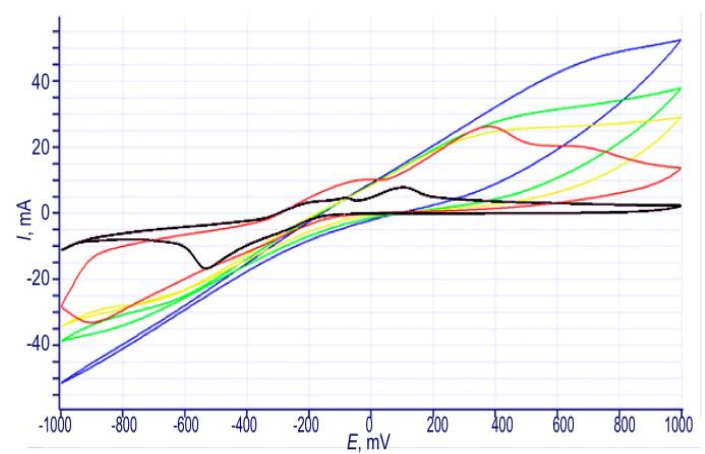

(b)

Figure 1 Cyclic voltammograms of copper in the salt layer (a) and alcohol layer (b) of electrolyte No. 1 at various potential scan rates: $1 \mathrm{mV} / \mathrm{s}$ (black), $5 \mathrm{mV} / \mathrm{s}$ (red), $25 \mathrm{mV} / \mathrm{s}$ (yellow), $50 \mathrm{mV} / \mathrm{s}$ (green), and $100 \mathrm{mV} / \mathrm{s}$ (blue)

Under cathodic polarization at a potential scan rate of $1 \mathrm{mV} / \mathrm{s}$ (i.e., in the opposite direction of the potential sweep), the remains of insoluble $\mathrm{Cu}_{2} \mathrm{O}$ and $\mathrm{Cu}(\mathrm{OH})_{2}$ were reduced to pure $\mathrm{Cu}$ at potentials of $-300 \mathrm{mV}$ and $-500 \mathrm{mV}$, respectively, which corresponded to reverse reactions (Equations 1 and 2). This is shown by dots on the corresponding curves in Figure 2a.

The presented CVs of $\mathrm{Cu}$ in the salt layer show that the current peaks diverge with an increase in the scanning speed, which indicates an electrochemically irreversible process when the electrochemical behavior of the system limits the kinetic process (i.e., electron transfer) (Mundinamani and Rabinal, 2014; Aristov and Habekost, 2015) (Figures 1a, 1b). More clearly pronounced peaks in the alcohol layer as compared to the salt layer are explained by the significantly higher ethanol content in it, compared to its trace content in the salt layer (Figure 1b). Lower values of the anode currents can be associated with both the lower electrical conductivity of the alcohol layer and with the formation of various compounds on the electrode surface. Current peaks in the potential range of $200 \mathrm{mV}$ and $400 \mathrm{mV}$, according to the Pourbaix diagram, correspond to the formation of $\mathrm{CuO}$ (Figure $1 \mathrm{~b})$.

In the absence of additional oxidant, three characteristic peaks were observed in CVs with a low potential scan rate of $1 \mathrm{mV} / \mathrm{s}$ that apparently competed with ethanol during adsorption on active surface regions (Figure 2).

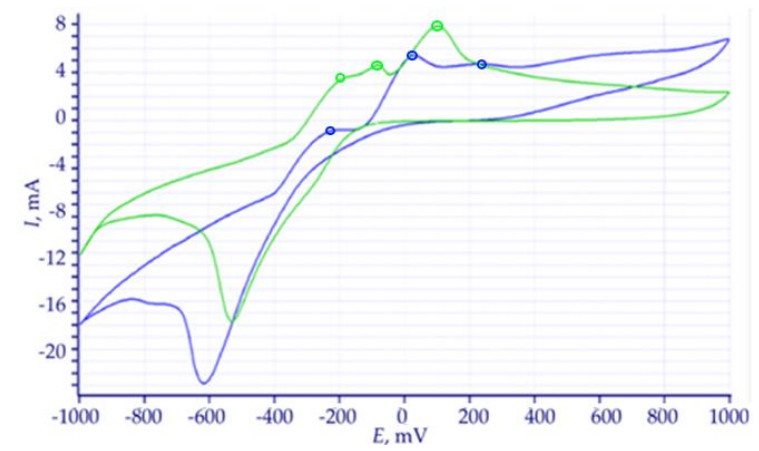

(a)

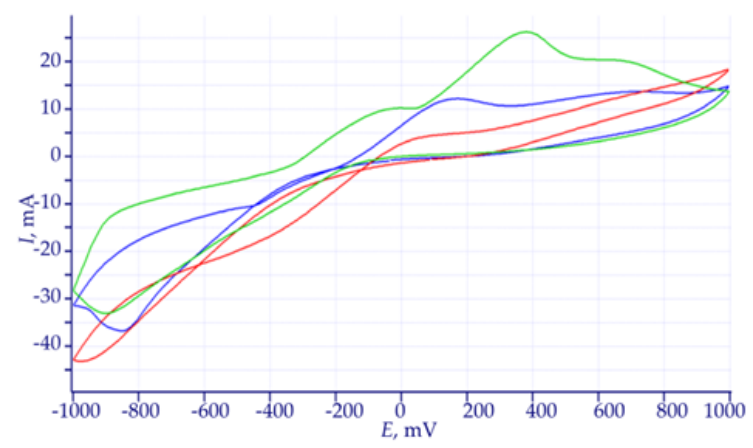

(b)

Figure 2 Cyclic voltammograms of copper in the alcohol layer of electrolyte No. 1 at a scan rate of $1 \mathrm{mV} / \mathrm{s} \mathrm{(a)} \mathrm{and} 5 \mathrm{mV} / \mathrm{s}$ (b) in the absence of an additional oxidizing agent (green), in the presence of $0.5 \mathrm{ml}$ of hydrogen peroxide (blue), and in the presence of $1.5 \mathrm{ml}$ of hydrogen peroxide (red) 
The first peak, at a potential of $-200 \mathrm{mV}$, was associated with the formation of $\mathrm{Cu}_{2} \mathrm{O}$ on the surface. The second was registered at a potential exceeding $-100 \mathrm{mV}$, and the third was observed as a potential higher than $100 \mathrm{mV}$. In the presence of the additional oxidant, the first and third peaks shifted to negative potentials by almost $100 \mathrm{mV}$ and were -250 $\mathrm{mV}$ and $0 \mathrm{mV}$, respectively (Figure 2a, green line). The second peak totally disappeared, which indicated the exclusion of one of the reactions. The addition of hydrogen peroxide to the electrolyte leads to a strong inhibition of reaction (Equation 2) by binding hydroxide ions (OH-) and to a decrease (termination) of the formation of $\mathrm{Cu}(\mathrm{OH})_{2}$, followed by the formation of $\mathrm{CuO}$ by reaction (Equation 3) (peak 3):

$$
\mathrm{Cu}_{2} \mathrm{O}+2 \mathrm{OH}^{-}=2 \mathrm{CuO}+\mathrm{H}_{2} \mathrm{O}+2 \mathrm{e}
$$

These conclusions are consistent with the Pourbaix diagram, according to which, at $\mathrm{pH}$ values less than 12 , the formation of $\mathrm{CuO}$ proceeds from $\mathrm{Cu}_{2} \mathrm{O}$ bypassing the formation of $\mathrm{Cu}(\mathrm{OH})_{2}$. It can also be seen (Figures 2a, 2b) that in the presence of the additional oxidizing agent in the solution, in particular hydrogen peroxide, the dissolution currents decreased, which was associated with the facilitation of the oxidation processes and the formation of oxides on the surface.

With an increase in the potential scan rate up to $5 \mathrm{mV} / \mathrm{s}$, the first and third peaks shifted to the positive potential region and reached $50 \mathrm{mV}$ and $350 \mathrm{mV}$, respectively (Figure $2 \mathrm{~b}$ ). In the presence of the oxidizing agent, they shifted to negative potentials by almost $200 \mathrm{mV}$ and reached $-300 \mathrm{mV}$ and $150 \mathrm{mV}$, respectively.

The CVs of $\mathrm{Cu}$ in the salt and alcohol layers at the various scan rates are compared in Figure 3. In the figure, the curves show that the rate of $\mathrm{Cu}$ dissolution in the salt layer is at least three times higher than in the alcohol layer. The CV shape of $\mathrm{Cu}$ in the alcohol layer also changed in accordance with an increase in the scan rate. At a low potential scan rate $(1 \mathrm{mV} / \mathrm{s})$, three characteristic oxidation regions were clearly observed on the anode curve (Figure 3a, blue line) near the potentials of $-200 \mathrm{mV},-100 \mathrm{mV}$, and $100 \mathrm{mV}$. As the scan rate increased to $5 \mathrm{mV} / \mathrm{s}$, these areas shifted in a positive direction to $-100 \mathrm{mV}, 50 \mathrm{mV}$, and $350 \mathrm{mV}$. In this case, the dissolution currents also increased (Figure $3 \mathrm{~b}$ ). At a scan rate of $25 \mathrm{mV} / \mathrm{s}$, the regions merged into one. In the potential range from $250 \mathrm{mV}$ to $300 \mathrm{mV}$, the dissolution currents remained the same.

With reverse polarization in the salt layer, the CVs clearly showed two peaks in the potential range of $-300 \mathrm{mV}$ and $-550 \mathrm{mV}$ (Figure $3 \mathrm{a}$, red line). The peak at $-550 \mathrm{mV}$ appeared to correspond to a reduction of $\mathrm{Cu}_{2} \mathrm{O}$ to metallic $\mathrm{Cu}$. The peak at $-300 \mathrm{mV}$ was associated with the reduction of $\mathrm{Cu}(\mathrm{OH})$ and $\mathrm{CuO}$. The observed dependences can be compared with the behavior of the oxidized surface of others, including noble metals, when particles with a higher oxidation state, formed at a higher potential, are removed first, under the change of the potential scan rate direction (Giri and Sarkar, 2016). The redox properties of copper oxides are complex and involve many steps. Proceeding from the fact that the driving force for the reduction of $\mathrm{CuO}$ to $\mathrm{Cu}$ is greater than for $\mathrm{Cu}(\mathrm{OH})_{2}$ to $\mathrm{Cu}$, it seems that the predominant reduction of $\mathrm{CuO}$ to metallic $\mathrm{Cu}$ occurs, the rest of the oxides are reduced at lower potentials. With a further increase in the scan rate, the CV shapes and their half-waves of oxidation and reduction change. As shown in Figure 3c, the peaks become more shallow, with the peaks in the anodic region merging into one at a potential scan rate of $25 \mathrm{mV} / \mathrm{s}$.

The peaks in the cathode region shifted to the negative potential region by more than $200 \mathrm{mV}$ compared to those at a scan rate of $1 \mathrm{mV} / \mathrm{s}$. In this case, the rate of $\mathrm{Cu}$ dissolution was four times higher because the thickness of the diffusion layer decreased and the rate of the electrochemical processes changed with an increase in the scan rate. In the process 
of anodic polarization as a result of CV the competition between the electrode reaction and diffusion, higher scan rates promote electrochemical irreversibility, controlled by the rate of electron transfer (Mundinamani and Rabinal, 2014; Aristov and Habekost, 2015). An increase in the dissolution rate of $\mathrm{Cu}$ due to a decrease in the thickness of the diffusion layer and a change in the rate of electrochemical processes with an increase in the scanning rate is clearly seen from the comparison of Figures 3a, 3b, 3c.

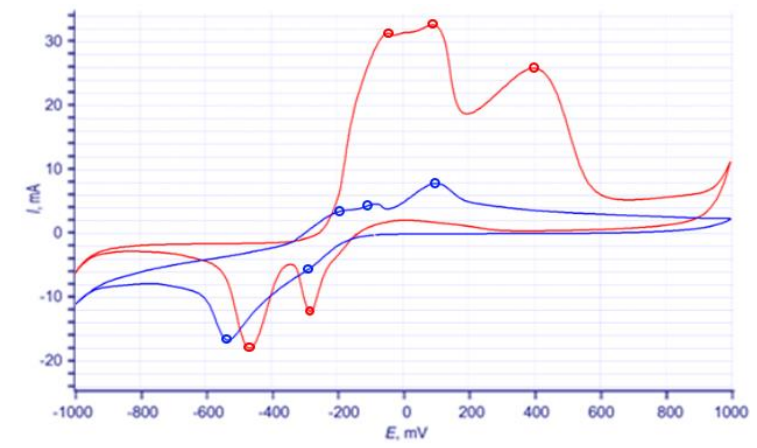

(a)

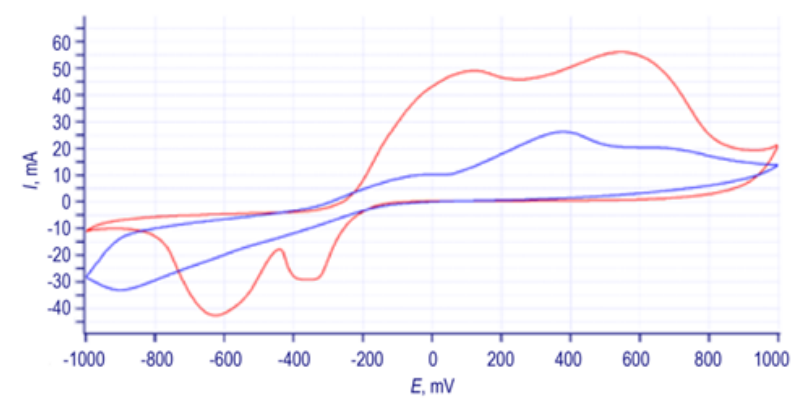

(b)

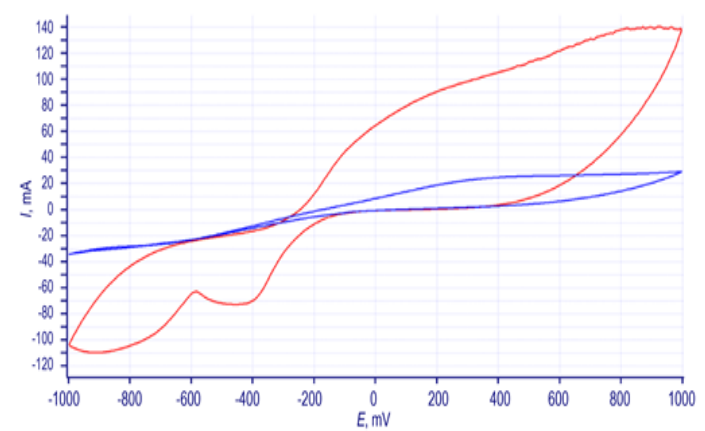

(c)

Figure 3 Cyclic voltammograms of copper in alcohol (blue) and salt (red) layers of electrolyte No. 1 at scan rates of $1 \mathrm{mV} / \mathrm{s}(\mathrm{a}), 5 \mathrm{mV} / \mathrm{s}(\mathrm{b})$, and $25 \mathrm{mV} / \mathrm{s}$ (c)

Thus, the CVs show that an irreversible chemical reaction takes place in the alcohol layer on $\mathrm{Cu}$ in the anodic region, starting from $-350 \mathrm{mV}$, with the formation of a stable compound on its surface. This reaction reached its maximum at potentials of 200-300 mV. The irreversibility of this chemical reaction was evident by the absence of a peak on the anodic backward curve. An increase in the scan rate led to a decrease in the thickness of the electric double layer and therefore to an increase in the current density in the anode potential region. However, the shape of the curve remained the same, which confirms an irreversible chemical reaction on the surface of the $\mathrm{Cu}$ electrode.

According to a Pourbaix diagram, from $-200 \mathrm{mV}$ to $600 \mathrm{mV}$ (pH less than $13 \mathrm{pH}$ ) $\mathrm{Cu}$ typically forms copper oxides $\mathrm{Cu}_{2} \mathrm{O}$ and $\mathrm{CuO}$ in this potential and $\mathrm{pH}$ range (Takeno, 2005). To test this hypothesis, the CVs of a $\mathrm{Cu}$ electrode with a $\mathrm{CuO}$ oxide layer were determined (Figure 4). An oxide layer was obtained by cyclic polarization of $\mathrm{Cu}$ in the salt layer of electrolyte No. 2 with $\mathrm{KOH}$.

As shown in Figure 4, in the presence of $\mathrm{CuO}$ on the $\mathrm{Cu}$ surface, oxidation peaks in the anodic region at potentials of $-200 \mathrm{mV}$ and $50 \mathrm{mV}$ were less pronounced. The dissolution currents were almost two times lower than that of pure $\mathrm{Cu}$ at the same scan rate (Figure $3 b)$. When the scan rate direction was changed by reverse polarization, the oxides on the surface dissolved up to a potential of $-150 \mathrm{mV}$, which was relatively consistent with the 
lower limit of the thermodynamically possible region of copper oxides in the Pourbaix diagram.

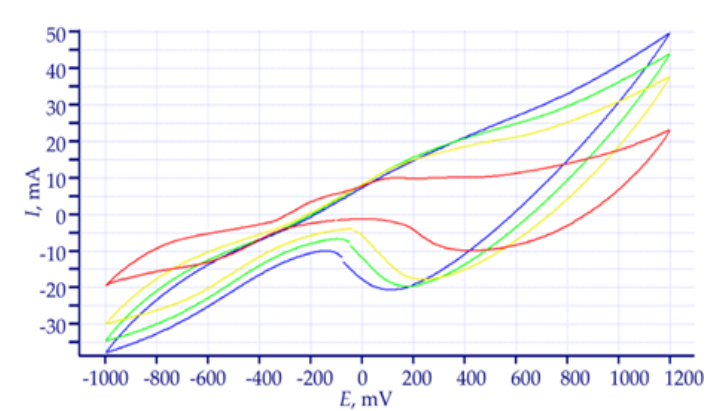

(a)

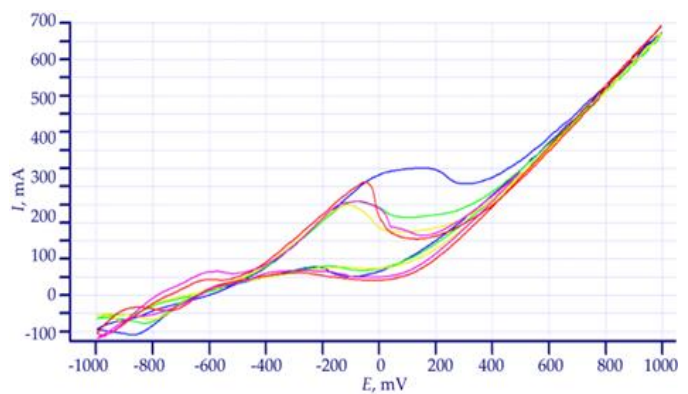

(b)

Figure 4 Cyclic voltammogram of copper electrode with a copper (II) oxide layer (a) and copper electrode without oxide layer (b) in the alcohol layer of electrolyte No. 2 at scan rates of $1 \mathrm{mV} / \mathrm{s}$ (magenta), $5 \mathrm{mV} / \mathrm{s}$ (red), $25 \mathrm{mV} / \mathrm{s}$ (yellow), $50 \mathrm{mV} / \mathrm{s}$ (green), and $100 \mathrm{mV} / \mathrm{s}$ (blue)

This was also evident from the increase in the slope of the curves in the region of cathodic polarization due to a decrease in the total ohmic resistance driven by the dissolution of the oxides on the $\mathrm{Cu}$ surface. With an increase in the scan rate to $25 \mathrm{mV} / \mathrm{s}$ and higher, both oxidation peaks disappeared, and the total ohmic resistance of the electrochemical system decreased, as evidenced by the change in the slope of the polarization curve $I=f(E)$. The shape of the curve still differed significantly from that of pure $\mathrm{Cu}$ under the same conditions.

A comparison of the $\mathrm{Cu}$ CVs for electrolyte No. 1 (Figure 1b) and No. 2 (Figure $4 \mathrm{~b}$ ) showed that in the second electrolyte, the dissolution currents were 12-14 times higher than in the first one. This finding can be explained by the inhibitory effect of the phosphate ions. The shape of the voltammogram of electrolyte No. 2 was also fundamentally different from that of No. 1. The anodic oxidation peak in electrolyte No. 2 was more negative than the peak in No. 1 by almost $300 \mathrm{mV}$, and the peak was not dependent upon the scan rate. In addition, a peak appeared during reverse scanning in the same potential range, and this peak was not dependent upon the scan rate. According to the shape of the obtained $\mathrm{CV}$, the peak corresponded to reversible electron mechanism followed by an irreversible chemical reaction $\mathrm{E}_{\mathrm{r}} \mathrm{C}_{\mathrm{i}}$ type with electrochemically reversible electron transfer followed by an irreversible homogeneous chemical reaction (Mundinamani and Rabinal, 2014; Aristov and Habekost, 2015). In this case, due to a slow homogeneous chemical reaction (compared to electron transfer), the amount of reducing agent in the system was very small. However, as the constant of the homogeneous reaction rate increased, the amount of reducing agent consumed in the chemical reaction also increased. As the scan rate increased, the ratio of anodic peaks to cathodic currents decreased because the reduced particles were consumed in the subsequent chemical reaction, resulting in fewer particles being oxidized than during anodic scanning.

Abd El Haleem and Abd El Aal (2006) observed two peaks during anodic oxidation of $\mathrm{Cu}$ in $0.1 \mathrm{M}$ sodium hydroxide $(\mathrm{NaOH})$ solution and two peaks during reverse scanning (i.e., when oxidized particles were reduced). The first peak on the polarization curve was associated with the formation of $\mathrm{Cu}_{2} \mathrm{O}$ by reaction (Equation 1). The second peak in the polarization curve was due to oxidation of $\mathrm{Cu}_{2} \mathrm{O}$ to $\mathrm{CuO}$ or $\mathrm{Cu}(\mathrm{OH})_{2}$ according to reaction Equation 3 or Equation 4:

$$
\mathrm{Cu}_{2} \mathrm{O}+2 \mathrm{OH}^{-}+\mathrm{H}_{2} \mathrm{O}=2 \mathrm{Cu}(\mathrm{OH})_{2}+2 \mathrm{e}
$$


The cathodic reduction curve was also characterized by the presence of two peaks that corresponded to the reduction of $\mathrm{Cu}(\mathrm{OH})_{2}$ and $\mathrm{Cu}_{2} \mathrm{O}$, respectively. It is assumed that the formation of $\mathrm{Cu}(\mathrm{OH})_{2}-$ occurs not as a result of direct oxidation of $\mathrm{Cu}$ but as a result of initial oxidation of $\mathrm{Cu}$ to $\mathrm{Cu}_{2} \mathrm{O}$ and subsequent dissolution of the copper oxides (Giri and Sarkar, 2016). Two possible reactions of $\mathrm{Cu}_{2} \mathrm{O}$ formation have been proposed: (1) twoelectron direct oxidation of $\mathrm{Cu}$, resulting in $\mathrm{Cu}_{2} \mathrm{O}$ formation; and (2) one-electron oxidation, where $\mathrm{Cu}(\mathrm{OH})_{2}$ is obtained first and then decomposed to $\mathrm{Cu}_{2} \mathrm{O}$ (Abd El Haleem and Abd El Aal, 2006).

To compare the catalytic activity of $\mathrm{Cu}$ in the oxidation of ethanol, its pulsed polarization was carried out in both electrolytes. The character of the change in the current during the pulse polarization of the copper electrode and the subsequent gasliquid chromatography of the electrolytes made it possible to compare the activity of the catalyst in both electrolytes and to determine the products of ethanol electrooxidation. The change in the current during pulsed polarization of the $\mathrm{Cu}$ electrode in electrolyte No. 1 is shown in Figure 5.
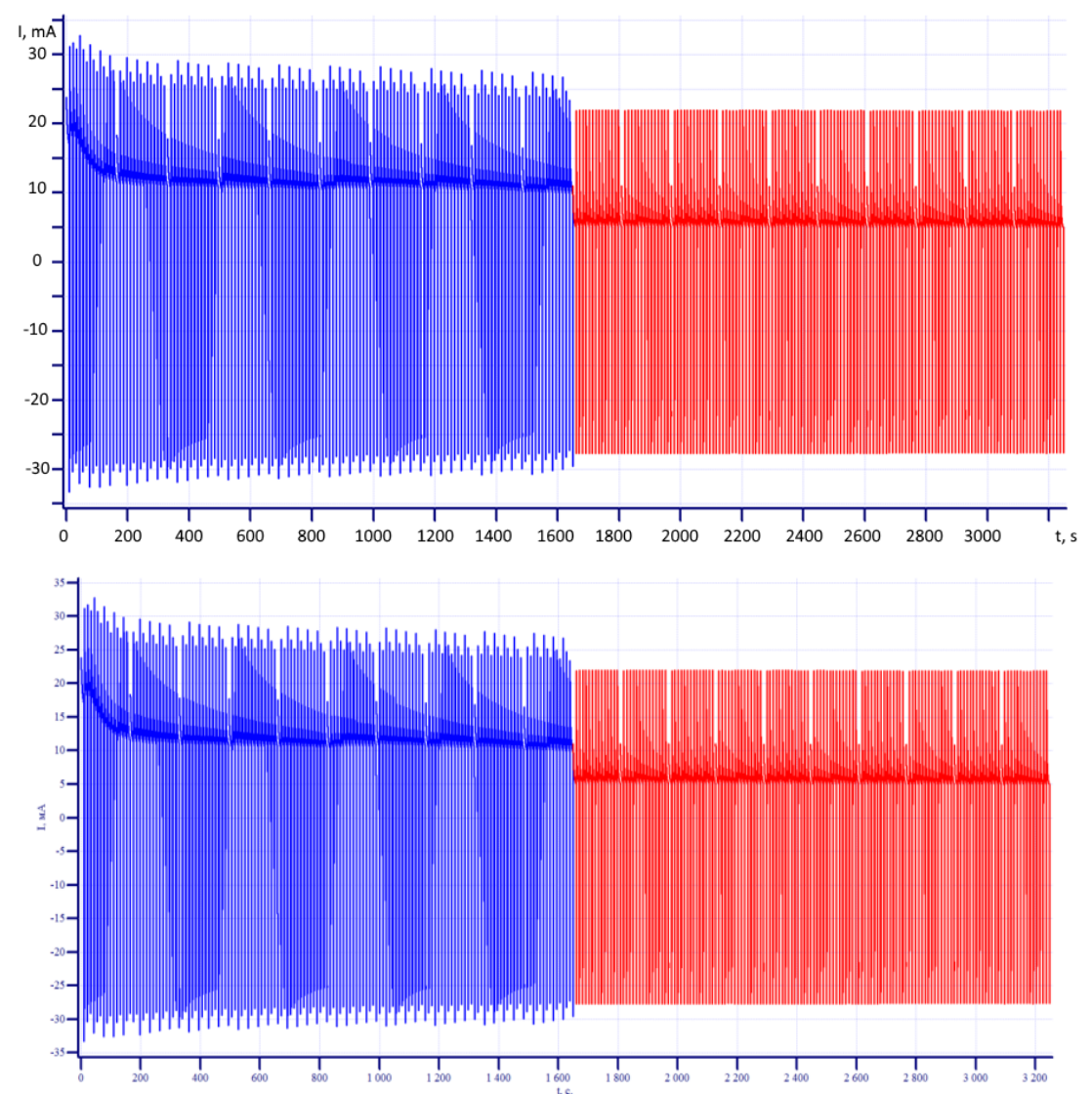

Figure 5 The change in the current during pulsed polarization of the copper electrode in electrolyte No. 1 in the first cycle (blue) and last cycle (red)

It can be seen in Figure 5, the current amplitudes decreased with time. After 2 hours of pulsed polarization, the lower salt layer of the electrolyte acquired a blue tint, and bright blue spots appeared on the surface of the $\mathrm{Cu}$ electrode. Analysis of the chromatogram of the alcohol mixture after oxidation on the Cur electrode in electrolyte No. 1 in pulsed polarization mode revealed the presence of acetaldehyde as a product of ethanol oxidation (Figure 6a). 


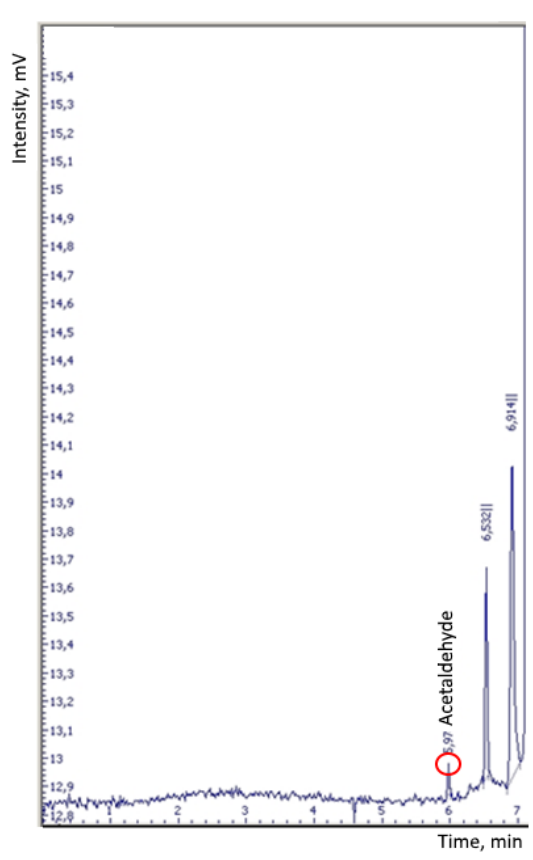

(a)

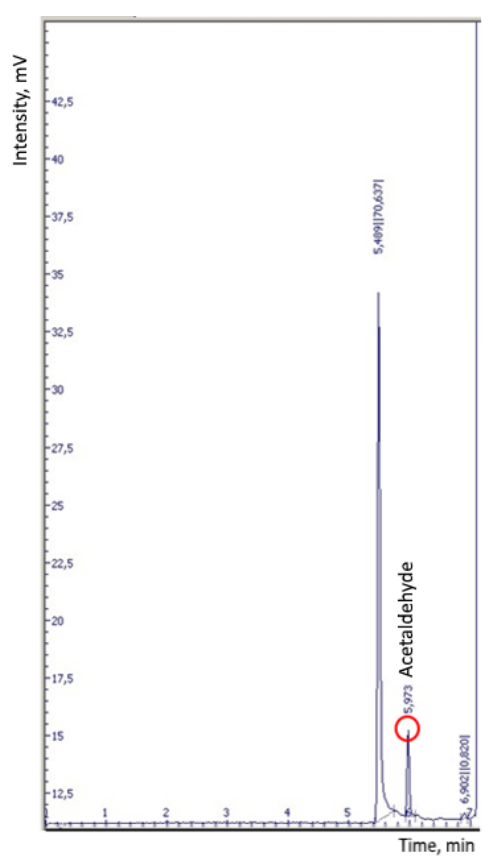

(b)

Figure 6 Gas-liquid chromatogram after 900 polarization pulses of the alcohol layer of electrolyte No. 1 (a) and dilution of the alcohol layer of electrolyte No. 2 by a factor of 5 (b)

The oxidation of ethanol on the $\mathrm{Cu}$ electrode in electrolyte No. 2 was carried out in pulsed mode in a similar way. Polarization was carried out by pulsed switching of the potential of the $\mathrm{Cu}$ electrode from $-400 \mathrm{mV}$ (holding time of $1 \mathrm{~s}$ ) to $+400 \mathrm{mV}$ (holding time of $10 \mathrm{~s}$ ). As shown in Figure 7, the dissolution currents in the anodic region decreased with time by almost a half.

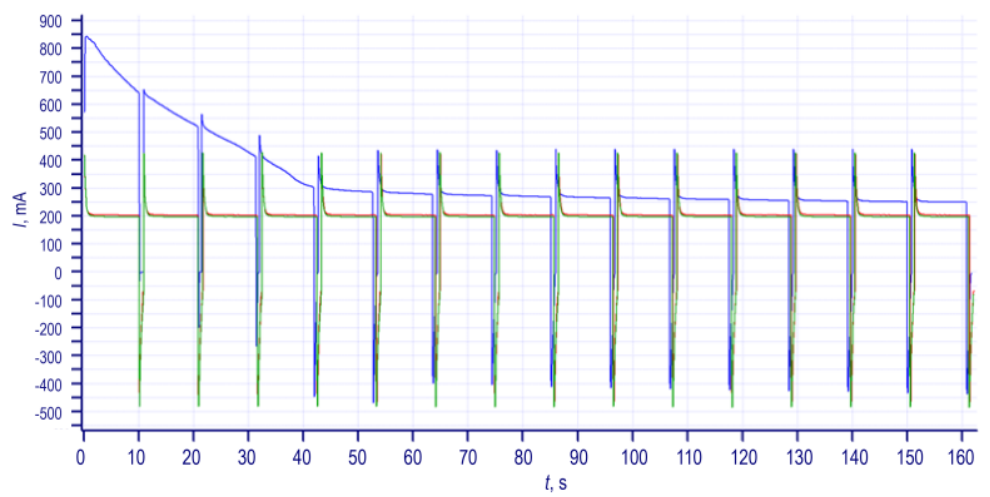

Figure 7 The change in the current during pulsed polarization of the copper electrode in electrolyte No. 2 in the first (blue) and last cycle (green)

Due to the high viscosity of electrolyte No. 2, all the samples were diluted with water by a factor of 5 before placing in the chromatographic column. Analysis of the chromatogram of the alcohol mixture in the second electrolyte revealed the presence of much more acetaldehyde in the electrolyte compared to that in the first electrolyte (Figure 6b). A comparison of the obtained chromatograms showed that the amount of acetaldehyde in electrolyte No. 2 was at least 5 times higher than that in electrolyte No. 1, pointing to higher catalytic activity of $\mathrm{Cu}$ in the electrolyte containing $\mathrm{KOH}$. The presence of ethanol oxidation products in the form of acetaldehyde indicated a C2 pathway of alcohol oxidation in the studied systems. 
Ethanol oxidation is known to proceed through a series of complex reactions involving several sequential and parallel reaction stages, resulting in the formation of more than 40 volatile and adsorbed intermediates and their oxidative derivatives (Monyoncho et al., 2018). Although there are different opinions regarding the adsorbed states of intermediate products and the limiting stage of the process, in general, there is agreement on the existence of two pathways ( $\mathrm{C} 1$ and $\mathrm{C} 2$ ) of ethanol oxidation. According to the $\mathrm{C} 1$ pathway, ethanol oxidizes to $\mathrm{CO}_{2}$, releasing 12 electrons and generating a cell voltage of $1.14 \mathrm{~V}$. The $\mathrm{C} 2$ pathway results mainly in the formation of acetic acid (or acetate in alkaline solutions) by delivering four electrons and/or acetaldehyde by delivering two electrons. Usually, the C2 pathway predominates in the ethanol oxidation process (Lai et al., 2010), which was observed in our case.

The appearance of the surface compounds on the $\mathrm{Cu}$ electrodes in the considered electrolytes differed, as shown in Figure 8. The surface compounds on the Cu electrode in electrolyte No. 1 consisted mainly of monovalent and bivalent $\mathrm{Cu}$ compounds and were green in color. A green color is typical of monovalent $\mathrm{Cu}$ compounds $\left(\mathrm{CuOH}\right.$ or $\left.\mathrm{Cu}_{2} \mathrm{O}\right)$, whereas a blue color is typical of bivalent $\mathrm{Cu}\left(\mathrm{CuO}\right.$ or $\left.\mathrm{Cu}(\mathrm{OH})_{2}\right)$. After pulsed polarization, the lower aqueous layer of electrolyte No. 1 acquired a blue tint (Figure 8a). The oxide film on the surface of the $\mathrm{Cu}$ electrode in electrolyte No. 2 had a black color, which is typical of trivalent $\mathrm{Cu}$ compounds $\left(\mathrm{Cu}_{2} \mathrm{O}_{3}\right)$. Figure $8 \mathrm{~b}$ clearly shows the upper oxidized alcohol phase of electrolyte No. 2 .

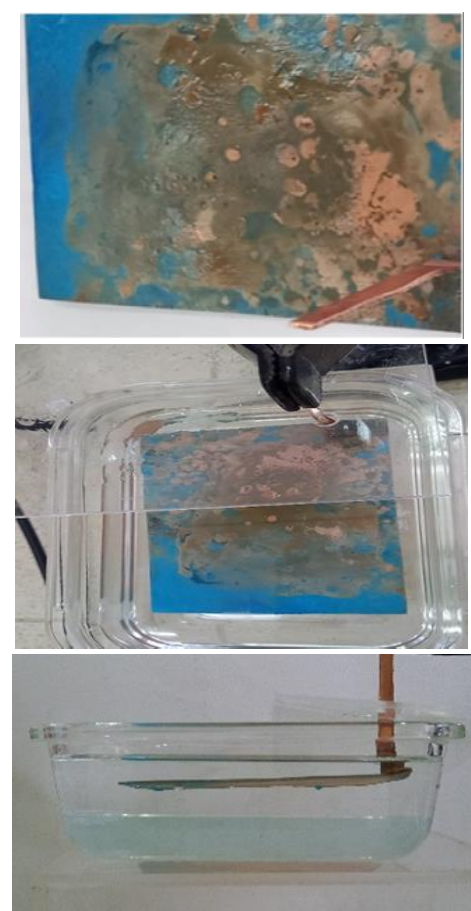

(a)

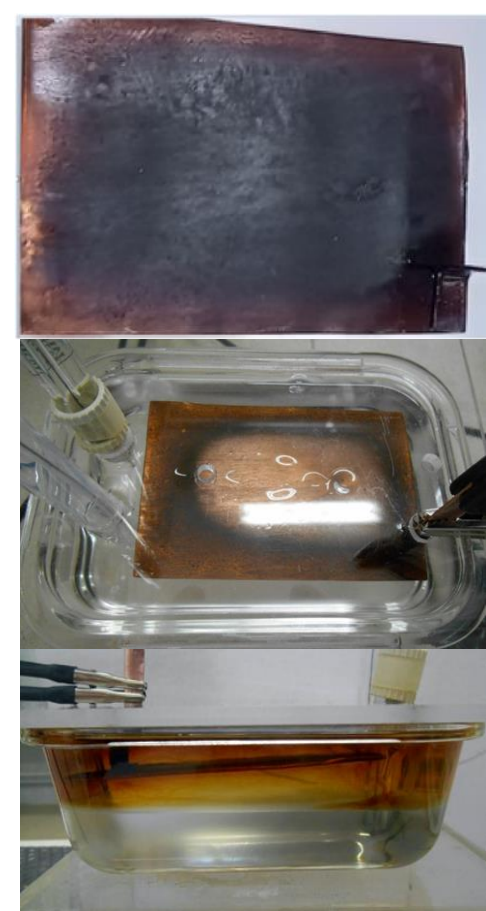

(b)

Figure 8 The appearance of the surface compounds on the copper electrodes and cells after pulsed polarization in the alcohol layer of electrolyte No. 1 (a) and electrolyte No. 2 (b)

Thus, the possibility of using $\mathrm{Cu}$ as a catalyst for the oxidation of ethanol in alkaline nonflowing membraneless fuel cells in the proposed two-phase systems has been proven. To further increase the catalytic activity of $\mathrm{Cu}$ and enhance its commercial attractiveness as a catalyst, further research is needed to optimize its composition and structure and create bimetallic and multimetallic $\mathrm{Cu}$-based electrodes, including nanostructured ones. 


\section{Conclusions}

As shown in the present study, that the catalytic activity of $\mathrm{Cu}$ during the oxidation of EtOH in the electrolyte containing potassium hydroxide was at least five times higher than in the electrolyte containing potassium phosphates, at almost the same $\mathrm{pH}$ values. Analysis of the chromatograms obtained after charging and discharging the fuel cells revealed the presence of ethanol oxidation products in the form of acetaldehyde, which indicated that the predominant mechanism of oxidation of ethanol in both two-phase systems Ethanol $+\mathrm{K}_{3} \mathrm{PO}_{4}+\mathrm{H}_{2} \mathrm{O}$ and Ethanol $+\mathrm{KOH}+\mathrm{H}_{2} \mathrm{O}$ was $\mathrm{C} 2$. This indicates that the use of a copper electrode in No. 2 electrolyte in membraneless fuel cells is promising. The use of inexpensive copper catalysts instead of platinum catalysts, the absence of a membrane, and an acceptable rate of ethanol oxidation at room temperature allows the proposed fuel cells to be considered for use as a power source for small portable devices or remote sensors.

\section{Acknowledgements}

The study was carried out with the financial support of the Russian Foundation for Basic Research within the framework of scientific project No.19-58-60002 UAR_t "A new type of membraneless fuel cells based on immiscible liquids, intended mainly for renewable fuels."

\section{References}

Abd El Haleem, S.M., Abd El Aal, E.E., 2006. Electrochemical Behavior of Copper in Alkaline-Sulfide Solutions. Corrosion, Volume 62(2), pp. 121-128

Almukhlifia, H.A., Burns, R.C., 2015. Oxidative Dehydrogenation of Isobutane to Isobutene by Pyrovanadates, $\mathrm{M}_{2} \mathrm{~V}_{2} \mathrm{O}_{7}$, where $\mathrm{M}$ (II) $=\mathrm{Mn}, \mathrm{Co}, \mathrm{Ni}, \mathrm{Cu}$ and $\mathrm{Zn}$, and $\mathrm{CO}_{2} \mathrm{VO}_{4}$ and $\mathrm{ZnV}_{2} \mathrm{O}_{4}$ : The Effect of Gold Nanoparticles. Journal of Molecular Catalysis A: Chemical, Volume 408, pp. 26-40

Aristov, N., Habekost, A., 2015. Cyclic Voltammetry a Versatile Electrochemical Method Investigating Electron Transfer Processes. World Journal of Chemical Education, Volume 3(5), pp. 115-119

Berawi, M.A., 2019. The Role of Industry 4.0 in Achieving Sustainable Development Goals. International Journal of Technology, Volume 10(4), pp. 644-647

Berawi, M.A., Suwartha, N., Surjandari, I., Zagloel, T.Y.M., Asvial, M., Harwahyu, R., Suryanegara, M., Setiawan, E.A., Maknun, I.J., Kusrini, E., Kartohardjono, S., Sofyan, N., Yuwono, A.H., Harjanto, S., Putra, N., Budiyanto, M.A., Whulanza, Y., 2020. Accelerating Sustainable Energy Development through Industry 4.0 Technologies. International Journal of Technology, Volume 11(8), pp. 1463-1467

Bueno, L., Paixao, T.R.L.C., 2011. A Copper Interdigitated Electrode and Chemometrical Tools Used for the Discrimination of the Adulteration of Ethanol Fuel with Water. Talanta, Volume 87(15), pp. 210-215

El Attar, A., Oularbi, L., Chemchoub, S., El Rhazi, M., 2021. Effect of Electrochemical Activation on the Performance and Stability of Hybrid (PPy/ $\mathrm{Cu}_{2} 0$ nanodendrites) for Efficient Ethanol Oxidation in Alkaline Medium. Journal of Electroanalytical Chemistry, Volume 885, https://doi.org/10.1016/j.jelechem.2021.115042

Fahim, A.E., Hameed, R.M.A., Allam, N.K., 2018. Synthesis and Characterization of CoreShell Structured M@Pd/SnO2-graphene [M = Co, $\mathrm{Ni}$ or $\mathrm{Cu}]$ Electrocatalysts for Ethanol Oxidation in Alkaline Solution. New Journal of Chemistry, Volume 42(8), pp. 6144-6160 
Freitasa, I.C., Damyanovab, S., Oliveirac, D.C., Marquesd, C.M.P., Buenoa, J.M.C., 2014. Effect of $\mathrm{Cu}$ Content on the Surface and Catalytic Properties of $\mathrm{Cu} / \mathrm{Zrco}_{2}$ Catalyst for Ethanol Dehydrogenation. Journal of Molecular Catalysis A: Chemical, Volume 381, pp. 26-37

Gao, D., McCrum, I.T., Deo, S., Choi, Y.-W., Scholten, F., Wan, W., Chen, J.G., Janik, M.J., Roldan Cuenya, B., 2018. Activity and Selectivity Control in $\mathrm{CO}_{2}$ Electroreduction to Multicarbon Products Over Cuox Catalysts Via Electrolyte Design. ACS Catalysis, Volume 8, pp. 10012-10020

Giri, S.D., Sarkar, A., 2016. Electrochemical Study of Bulk and Monolayer Copper in Alkaline Solution. Journal of the Electrochemical Society, Volume 163(3), pp. H252H259

Giziński, D., Brudzisz, A., Santos, J., Strixino, F., Stępniowski, W., Czujko, T., 2020. Nanostructured Anodic Copper Oxides as Catalysts in Electrochemical and Photoelectrochemical Reactions. Catalysts, Volume 10(11), pp. 1338-1376

Hardi, G.W., Rahman, S.F., 2020. Amperometric Detection of Dopamine based on a Graphene Oxide/PEDOT:PSS Composite Electrode. International Journal of Technology, Volume 11(5), pp. 974-983

Khalil, M., Liu, N., Lee, R.L., 2018. Super-Nernstian Potentiometric pH Sensor based on the Electrodeposition of Iridium Oxide Nanoparticles. International Journal of Technology, Volume 9(3), pp. 446-454

Kusrini, E., Setiawan, E.A., Sofyan, N., 2018. Exploring Potential Materials, Science, and Technology for Improvements in Reusing Energy and Waste. International Journal of Technology, Volume 9(6), pp. 1085-1091

Kusrini, E., Kartohardjono, S., Putra, N.S.D., Budiyanto, M.A., Wulanza, Y., Berawi, M.A., Suwartha, N., Maknun, I.J., Asvial, M., Setiawan, E.A., Suryanegara, M., Harwahyu, R., Yatmo, Y.A., Atmodiwiryo, P., 2020. Science, Engineering and Technology for Better Future. International Journal of Technology, Volume 11(7), pp. 1286-1291

Lai, S.C.S., Kleijn, S.E.F., Ozturk, F.T.Z., van Rees Vellinga, V.C., Koning, J., Paramaconi Rodriguez, P., Koper, M.T.M., 2010. Effects of Electrolyte pH and Composition on the Ethanol Electro-Oxidation Reaction. Catalysis Today, Volume 154(1-2), pp. 92-104

Li, C., Kurniawan, M., Sun, D., Tabata, H., Delaunay, J.J., 2014. Nanoporous CuO Layer Modified Cu Electrode for High Performance Enzymatic and Non-Enzymatic Glucose Sensing. Nanotechnology, Volume 26(1), pp. 1-8

Liu, Y., Yu, H., Li, K., Xiang, K., Liu, H., 2020. Strategies to Improve the Performance of Copper-Based Catalyst for Electroreduction of $\mathrm{CO}<\mathrm{sub}>2</$ sub $>$ to Multi-Carbon Products. Chinese Science Bulletin, Volume 65(31), pp. 3360-3372

Masudin, I., Saputro, T.E., Arasy, G., Jie, F., 2019. Reverse Logistics Modeling Considering Environmental and Manufacturing Costs: A Case Study of Battery Recycling in Indonesia. International Journal of Technology, Volume 10(1), pp. 189-199

Monyoncho, E.A., Woo, T.K., Baranova, E.A., 2018. Ethanol Electrooxidation Reaction in Alkaline Media for Direct Ethanol Fuel Cells. Electrochemistry, Volume 15, pp. 1-57

Mundinamani, S.P., Rabinal, M.K., 2014. Cyclic Voltammetric Studies on the Role of Electrode, Electrode Surface Modification and Electrolyte Solution of an Electrochemical Cell. IOSR Journal of Applied Chemistry, Volume 7(9), pp. 45-52

Oznuluer, T., Demir, U., Dogan, H.O., 2018. Fabrication of Underpotentially Deposited $\mathrm{Cu}$ Monolayer/Electrochemically Reduced Graphene Oxide Layered Nanocomposites for Enhanced Ethanol Electro-Oxidation. Appl. Catal. B-Environ., Volume 235, pp. 56-65

Paixao, T.R.L.C., Beriotti, M., 2004. Development of a Breath Alcohol Sensor using a Copper Electrode in an Alkaline Medium. Journal of Electroanalytical Chemistry, Volume 571(1), pp. 101-109 
Paixao, T.R.L.C., Corbo, D., Bertotti, M., 2002. Amperometric Determination of Ethanol in Beverages at Copper Electrodes in Alkaline Medium, Analytica Chimica Acta, Volume 472(1-2), pp. 123-131

Panah, N.B., Danaee, I., Ghamsari, Z.G., 2019. Effect of Electrochemical Surface Pretreatment on Electro-Catalytic Activity of Copper for Ethanol Oxidation. Surf. Engin. Appl. Electrochem. 2019, Volume 55, pp. 630-637

Sato, A.G., Volanti, D.P., Freitas, I.C., Longo, E., Bueno, J.M.C., 2012. Site-Selective Ethanol Conversion Over Supported Copper Catalysts. Catalysis Communications, Volume 26, pp. 122-126

Scherzer, M., Girgsdies, F., Stotz, E., Willinger, M.G., Frei, E., Schlogl, R., Pietsch, U., Lunkenbein, T., 2019. Electrochemical Surface Oxidation of Copper Studied by In Situ Grazing Incidence X-ray Diffraction. The Journal of Physical Chemistry C, Volume 123 (21), pp. 13253-13262

Takeno, N., 2005. Atlas of Eh-pH Diagrams. Inter Comparison of Thermodynamic Databases. Geological Survey of Japan Open File Report No. 419. National Institute of Advanced Industrial Science and Technology, Japan

Tarantseva, K., Yakhkind, M., Politaeva, N., 2020a. Selection of Electrode Materials for Membrane Less Fuel Cells based on Immiscible Liquids. IOP Conference Series: Materials Science and Engineering, Volume 883, pp. 1-10

Tarantseva, K.R., Yakhkind, M.I., Korosteleva, A.V., Krasnaya, E.G., Parfenova, E.A., Kurochkina, 0.G., 2020b. Study of Electromotive Force of a New Type of Membraneless Fuel Cell Operating on Renewable Fuel. E3S Web of Conferences, Volume 161, pp. 1-5

Tarantseva, K.R., Yakhkind, M.I., Mishra, A., Marynova, M.A., Polyanskova, E.A., Goryacheva, A.A., 2020c. Systems of Two Immiscible Liquids for a New Type of Membraneless Fuel Cells using Renewable Fuel. E3S Web of Conferences, Volume 161, pp. 1-5

Wan, Y., Zhang, Y., Wang, X., Wang, Q., 2013. Electrochemical Formation and Reduction of Copper Oxide Nanostructures in Alkaline Media. Electrochemistry Communications, Volume 36, pp. 99-102

Wu, X., Fang, G., Liang, Z., Leng, W., Xu, K., Jiang, D., Ni, J., Li, X., 2017. Catalytic Upgrading of Ethanol to n-butanol over $\mathrm{M}-\mathrm{Ce} 02 / \mathrm{AC}(\mathrm{M}=\mathrm{Cu}, \mathrm{Fe}, \mathrm{Co}, \mathrm{Ni}$ and $\mathrm{Pd})$ Catalysts. Catalysis Communications, Volume 100, pp. 15-18 